Ryszarda BULAS

(Lublin, KUL)

\title{
CHRZEŚCIJAŃSKIE ITINERARIA DO MIEJSC ŚWIĘTYCH OD II DO VIII WIEKU*
}

Literatura badawcza na temat pielgrzymek i itinerariów jest już dziś ogromna, tak że nawet polski czytelnik zainteresowany tą problematyką może zebrać wystarczający materiał do zbadania tego tematu. W Polsce problemem peregrynacji i itinerariami zajmowali się głównie M. Starowieyski, M. Wipszycka, P. Iwaszkiewicz, A. Witkowska, A. Bober i J. Czuj ${ }^{1}$. Spośród obcych należy wymienić m.in. takich badaczy, jak: E.D. Hunt, P. Devos. S. Elm, C. Mango, G. Vikan, J. Wilkinson, P. Maraval i P. Geyer²; większość starożytnych itinerariów do miejsc świętych została już przetłumaczona na język polski ${ }^{3}$, wobec czego niniejszy artykuł jest jedynie zestawieniem zebranego materiału.

* Artykuł oparty jest na materiałach z wygłoszonego komunikatu na Sympozjum Kazimierskim, które odbyło się w październiku 2004 r. w Kazimierzu Dolnym, a poświęcone było miejscom świętym, por. Sympozja Kazimierskie poświęcone kulturze późnego antyku i wczesnego chrześcijaństwa, t. 5: Miejsca święte w epoce późnego antyku, red. B. Iwaszkiewicz-Wronikowska - D. Próchniak, Lublin 2005.

${ }^{1}$ Por. P. Iwaszkiewicz, Wczesnochrześcijańskie opisy podróży do Ziemi Świętej, „Meander” 45 (1990) 13-19; M. Starowieyski, Pielgrzymki do Ziemi Świętej w wiekach II-IV a Biblia, „Bobolanum" 4 (1993) 146-159. Pielgrzymki w kulturze średniowiecznej Europy. Materiały z Seminarium Mediewistycznego, red. J. Wiesiołowski, Poznań 1993; P. Iwaszkiewicz, Do Ziemi Świętej. Najstarsze opisy pielgrzymek do Ziemi Świętej (IV-VIII w.), wstęp M. Starowieyski, OŻ 13, Kraków 1994; tenże, Wczesnochrześcijańskie i późnoantyczne tacińskie opisy podróży do Ziemi Świętej (przed wyprawami krzyżowymi), w: Peregrinationes. Pielgrzymki w kulturze dawnej Europy, red. H. Manikowska - H. Zaremska, Warszawa 1995, 98-101 oraz inne szczegółowe tematy, głównie autorstwa M. Starowieyskiego i P. Iwaszkiewicza widoczne w kolejnych przypisach.

2 Podstawowa literatura: P. Geyer, Itineraria Hierosolymitana saec. III-VIII, Wien 1898 (= CSEL 39); Itineraria et alia geographica, CCL 175, Turnholti 1965; J. Wilkinson, Jerusalem pilgrims before the crusades, Warminster 1977; E.D. Hunt, Holy Land pilgrimage in the Later Roman Empire AD 312-460, Oxford 1982; P. Maraval, Lieux saints et pèlerinages d'Orient. Histoire et géographie des origines à la conquête arabe, Paris 1985; P. Maraval, Les Itinéraires de pèlerinage en Orient (entre le $4^{e}$ et le $7^{e} \mathrm{~s}$.), w: Akten des XII. Internationalen Kongresses für christliche Archäologie (Bonn, 22-28. September 1991), Teil 1, Münster 1995, 291-300.

${ }^{3}$ Przetłumaczono, wymieniając w porządku chronologicznym: Itinerarium Pielgrzyma z Bordeaux, Dziennik Egerii, Breviarius de Hierosolyma, De situ terrae sanctae Teodozjusza, Itinerarium Pseudo-Antonina z Piacenzy, List Waleriusza z Bierzo i De locis sanctis Adamnana. Czeka na swych thumaczy m.in. De locis sanctis Bedy Czcigodnego, CCL 175, 251-280 lub CSEL 39, 301-324. 
Do zebranych tekstów itineraryjnych badacze podchodzą z różnych punktów widzenia: jako do dokumentu epoki, przyczynku do historii Kościoła, czy źródła do badań nad językiem; zjawisko peregrynacji bada się także z punktu widzenia antropologii. Uczeni dokonują też podziału źródeł ze względu na ich obszerność, poziom i język.

Wczesne źródła dzielone są na: przednicejskie i ponicejskie ${ }^{4}$, czyli II- III oraz IV wiek. Należy dodać jeszcze okres przekazów z okresu V-VIII wiek. Datą graniczną omawianych tu materiałów jest koniec VIII wieku, wyznaczony pierwszą ważną schizmą między Wschodem i Zachodem, ekspansją islamu oraz powstaniem Cesarstwa Zachodniego Karola Wielkiego.

1. Wiek II-III. Najstarsze świadectwo podróży do Palestyny omawiają M. Starowieyski i E. Wipszycka; II wieku (przed 190) sięga pierwszy przekaz, zawarty u apologety Melitona z Sardes, który w liście do przyjaciela Onezyma opisuje on swoją podróż z Sardes do Jerozolimy w celu dokładnego poznania kanonu Ksiagg Swiętych i utwierdzenia swego przyjaciela w wierze:

„Byłem na Wschodzie i dostałem się do miejsca, gdzie się to wszystko głosiło i działo, tam też poznałem księgi Starego Testamentu, a ich zestawienie tobie posyłam"s.

W roku 213 kapadocki biskup Aleksander, ponieważ miał sen, udał się do Jerozolimy, „na modlitwę i zwiedzanie miejsc świętych" ${ }^{\text {. }}$. Około 230 r. podróż do Palestyny odbył Orygenes by „ujrzeć ślady Jezusa i Jego uczniów”, „ustalał też realia Pisma Swiętego" ". Na spotkanie z Orygenesem do Palestyny przybył biskup kapadocki Firmilian ${ }^{8}$. W połowie III wieku podróż po Jerozolimie odbył także kapłan Pionius ze Smyrny, z którego mowy obronnej przed śmiercią męczeńską dowiadujemy się, że ,objechał całą ziemię Judei, przekroczył Jordan i oglądał okolice poświadczające gniew Boży [Sodoma], a także spalone ziemie w pobliżu Morza Martwego".

${ }^{4}$ Por. M. Starowieyski, Pielgrzymki do Ziemi Świętej w wiekach II-IV a Biblia, „Bobolanum” 4 (1993) 148-151.

${ }^{5}$ Melito Sardensis, Epistula ad Onesimum, w: Eusebius, HE IV 26, 14, SCh 31, 211, thum. A. Lisiecki, POK 3, Poznań 1924, 187; por. E. Wipszycka, Pielgrzymki starożytne: problemy definicji i cezur, w: Peregrinationes. Pielgrzymki w kulturze dawnej Europy, s. 23-24; Starowieyski, Pielgrzymki do Ziemi Świętej, s. 149-150.

${ }^{6}$ Eusebius, HE VI 11, 1, SCh 41, 100, POK 3, 263; por. Wipszycka, Pielgrzymki starożytne, s.24; Starowieyski, Pielgrzymki do Ziemi Świętej, s. 150.

${ }^{7}$ Por. Origenes, Commentarius in Joannem VI 40, 204, SCh 157, 286, thum. S. Kalinkowski, PSP 28/1, 199; Contra Celsum I 51, SCh 132, 214; zob. Starowieyski, Pielgrzymki do Ziemi Świętej, s. 150.

${ }^{8}$ Por. Eusebius, HE VI 27, SCh 41, 121, POK 3, 283; zob. Wipszycka, Pielgrzymki starożytne, s. 24; Starowieyski, Pielgrzymki do Ziemi Świętej, s. 151.

${ }^{9}$ Passio Pionii presbyteri eiusque sociorum 4, 18 i 20, ed. H. Musurillo, Oxford 1972, 140-142; Starowieyski, Pielgrzymki do Ziemi Świętej, s. 151; Wipszycka, Pielgrzymki starożytne, s. 24-25. 
Analiza tekstów z II i III wieku pozwala M. Starowieyskiemu i E. Wipszyckiej skonstatować, że w okresie przedkonstantyńskim ruch pielgrzymkowy do Ziemi Świętej nie miał celów duchowych, lecz krajoznawcze, że był wynikiem studiów nad Biblia, rodzajem „weryfikacji” przekazu biblijnego i historycznej ewidencji ${ }^{10}$. Miały one charakter wizyty i pozbawione były spójnego planu zwiedzania. Impulsem takiej podróży była chęć poszerzenia wiedzy: szukano np. dobrych rękopisów biblijnych lub szukano archeologicznych pamiątek. Starowieyski nazywa ten typ pielgrzymki ,biblijną pielgrzymką uczonego"11. Zdaniem E. Wipszyckiej nic nie wskazuje na to, że Meliton sądził, iż jego obecność w miejscu uświęconym przez patriarchów i Chrystusa ma jakąś wartość samą w sobie ${ }^{12}$. W tym czasie nie ma też - jak podaje Starowieyski - żadnych katechez związanych z pielgrzymkami ${ }^{13}$.

Dość ograniczony ruch pielgrzymkowy do miejsc świętych w pierwszym okresie mógł też, zdaniem M. Starowieyskiego - wynikać z pewnych sformułowań Nowego Testamentu pochodzących m.in. od św. Jana $(4,21)$ i św. Pawła (Ef 2, 20-23; Ga 4, 11) wskazujących na nieufność Chrystusa do pielgrzymek ${ }^{14}$. Jego zdaniem, pewnym wytłumaczeniem tego zjawiska jest fakt, że większość miejsc kultowych Starego Testamentu była w rękach Żydów i judeochrześcijan niechętnie nastawionych do chrześcijan, a prawna sytuacja tych ostatnich była niepewna i przerywana prześladowaniami; jednak o pewnym ruchu pielgrzymkowym może - jego zdaniem - świadczyć fakt, że za czasów Hadriana postawiono świątynię Wenus na miejscu Golgoty, a gaj Adonisa nad grotą w Betlejem ${ }^{15}$. E. Wipszycka dodaje, że okres tzw. „małego pokoju" między panowaniem Waleriusza i Dioklecjana w III wieku, nie były tak złe, by uniemożliwiać podróż do miejsc świętych, odwiedzanych zresztą także przez Żydów ${ }^{16}$.

2. Wiek IV-VI. Przekazy pochodzące z okresu IV-VI wieku charakteryzują się nowym podejściem do miejsc świętych. Pojawiają się wówczas elementy, które pozwalają mówić o pewnej ewolucji zjawiska peregrynacji. Z tego czasu pochodzą świadectwa: Euzebiusza z Cezarei, pielgrzyma z Bordeaux, Cyryla Jerozolimskiego, Atanazego z Aleksandrii, Egerii, Grzegorza z Nysy, Hieronima, Nila z Ancyry, Eucheriusza, anonimowy Breviarius de Hierosoly-

${ }^{10}$ Por. Wipszycka, Pielgrzymki starożytne, s. 23-24; zob. też J. Wilkinson, Visits to Jewish tombs by early Christians, w: Akten des XII. Internationalen Kongresses für christliche Archäologie, Teil 1, s. 455.

${ }^{11}$ Starowieyski, Pielgrzymki do Ziemi Świętej, s. 151.

${ }^{12}$ Por. Wipszycka, Pielgrzymki starożytne, s. 24.

${ }^{13}$ Por. Starowieyski, Pielgrzymki do Ziemi Świętej, s. 150-151.

${ }^{14}$ Por. tamże, s. 149.

${ }^{15}$ Por. Hieronymus, Epistula 58, 3, ŹMT 55, Kraków 2010; Starowieyski, Pielgrzymki do Ziemi Świętej, s. 149.

${ }^{16}$ Por. Wipszycka, Pielgrzymki starożytne, s. 25. 
ma, De situ terrae sanctae Teodozjusza, Itinararium Antonina Piacenzy oraz Ody Andrzeja z Krety.

a). Euzebiusz z Cezarei (260-339) jest autorem trzech tekstów, w których zawarł swą wiedzę na temat miejsc świętych: Onomastikon, Historia Kościelna i Żywotu Konstantyna ${ }^{17}$. Przekazy Euzebiusza mają charakter faktograficzny. Źródła te omawia E. Wipszycka i P. Iwaszkiewicz. Onomastikon, napisany przed $331 \mathrm{r}$, jest alfabetycznym wykazem biblijnych miejscowości i ich identyfikacji z nazwami współczesnymi wraz z objaśnieniami geograficznymi i historycznymi. Został przełożony przez Hieronima z greki na łacinę z pewnymi poprawkami i uzupełnieniami. W Zywocie Konstantyna znajdują się wiadomości o grobie Chrystusa, a w Historii Kościelnej wiadomości o podróżach do Jerozolimy Firmiliana, Aleksandra, Melitona i Orygenesa.

b). Itinerarium autorstwa anonimowego pielgrzyma $\mathrm{z}$ Bordeaux ${ }^{18}$ jest suchą a nawet „bezbarwną i nudną” - jak piszą badacze - relacją z podróży do Jerozolimy. Jego twórcą jest pewien obywatel Bordeaux, który odbył podróż w 333 r. (przez Bordeaux, Alpy, górną Italię, Mediolan, Akwileję, Bałkany, Konstantynopol, Azję Mniejszą i Syrię) oraz opisał ją ok. 337 roku. Jego wiadomości są lakoniczne, choć trochę więcej pisze o Jerozolimie i jej okolicach (wspomina wzgórze Golgoty, krzyż i bazylikę Konstantyna). Skrupulatnie wymienił wszystkie miasta, wsie i zajazdy, a także odległości między miastami, dzięki czemu przekaz ten pozwala zrekonstruować system dróg oraz jest źródłem do badań dla archeologów i historyków zajmujących się rzymskim systemem komunikacji i historią gospodarczą cesarstwa. Zdaniem ks. M. Starowieyskiego, pielgrzym ten zna Biblię bardzo płytko, a jego opowiadania są naiwne: pisze bowiem o wielu cudownych rzeczach, jak np. o platanach sadzonych przez Jakuba, krwi Zachariasza, murze płaczu, o górze, na której Abraham złożył ofiarę, o grobowcu, w którym został pochowany Józef, o kolumnie, przy której Chrystus był biczowany, czy o źródle proroka Eliasza. Znamiennym jest fakt, że 22 razy powołuje się na Stary Testament, a tylko 9 razy na Nowy.

c). Cyryl Jerozolimski (320-386) w jednej ze swoich przedchrzcielnych katechez, w kontekście Pieśni nad Pieśniami $(2,10)$ wspomina ok. 340 r. o przedsionkach do zburzonego Grobu Chrystusa. Jego rozważania świadczą,

\footnotetext{
${ }^{17}$ Por. Eusebius, Onomasticon, PL 23, 859-928 (PG 23, 903-976); lub ed. E. Klostermann, GCS 2/1, Leipzig 1904; Eusebius - Hieronymus, De nominibus et situ Hebraicorum, PL 23, 859-928 (PG 23, 903-976); Iwaszkiewicz, Wczesnochrześcijańskie i późnoantyczne tacińskie opisy podróży, s. 99.

${ }^{18}$ Itinerarium Burdigalense, CSEL 39, 3-33 lub ed. O. Cunz, CCL 175, 1-26. Na temat tego Itinerarium zob. Pielgrzym z Burdigali i jego opis podróży do Jerozolimy, tłum. P. Iwaszkiewicz, „Meander” 46 (1991) 63-75; Iwaszkiewicz, Wczesnochrześcijańskie i późnoantyczne tacińskie opisy podróży, s. 98-99; tenże, Podróż z Bordeaux do Jerozolimy, OŻ 13, 73-78; Starowieyski, Pielgrzymki do Ziemi Świętej, s. 146-147; J. Wilkinson, Egeria's travels to Holy Land, Jerusalem Warminster 1980, 153-163; SWP 587-588; DACL VII/2, 1853-1858.
} 
że Grób Chrystusa był dla niego nie tylko faktem, ale - jak pisze E. Wipszycka - też miejscem duchowym ${ }^{19}$.

d). Atanazy z Aleksandrii (296-373) napisał list, zachowany jedynie w VII/ VIII-wiecznej syryjskiej kopii, do egipskiej wspólnoty dziewic (parthenoi), udających się do Jerozolimy i powracających stamtąd $\mathrm{d}^{20}$; napisany został w poł. IV wieku lub szerzej w latach 328-373. Atanazy nie opisuje w nim swojej pielgrzymki, lecz - jak pisze S. Elm - przedstawia w nim obraz życia ascetek z poł. IV wieku, dla których podróż do loca sancta była ustalonym zwyczajem. Podróży do Jerozolimy nie postrzega jako celu peregrynacji mniszek, lecz jako podróż duchową ${ }^{21}$.

e). Itinerarium Egeriii ${ }^{22}$, którego głównymi badaczami są R. Maraval i P. Delos, a w Polsce - ks. M. Starowieyskii ${ }^{23}$, powstało pół wieku po przekazie pielgrzyma z Bordeaux. Egeria napisała swój dziennik - list w czasie pielgrzymki, którą odbyła w latach 381-384; jego tekst skierowany jest do „sióstr” na Zachodzie. Zwiedziła ona większy niż pielgrzym z Bordeaux obszar, nie tylko Palestynę, lecz także Synaj, Egipt, Syrię, Izaurię i Konstantynopol; planowała - jak piszą znawcy tematu - także pielgrzymkę do grobu św. Jana w Efezie. Niekompletna druga część Itinerarium opisuje liturgię jerozolimską oraz zwyczaje związane z postem i katechumenatem. Zaginiona część Itinerarium zawierała opis drogi do Jerozolimy, pielgrzymkę po mieście i okolicach oraz podróż do Egiptu. Brakujące części badacze rekonstruują dziś na podstawie dwóch źródeł będących daleko idącą kopią dzieła Egerii: Listu mnicha wizygockiego z terenów hiszpańskiej Galicji - Waleriusza z Bierzo oraz De locis sanctis Piotra Diakona z XII wieku ${ }^{24}$. Egeria interesuje się głównie miej-

${ }^{19}$ Por. Cyrillus Alexandrinus, Catechesis 14, 9, PG 33, 833, thum. W. Kania: Katechezy przedchrzcielne i mystagogiczne, BOK 14, Kraków 2000, 216; zob. Wipszycka, Pielgrzymki starożytne, s. 27.

${ }^{20}$ Por. Athanasius Alexandrinus, Epistula ad virgines (syriace), ed. J. Lebon: Athanasiana Syriaca II, „Le Muséon” 41 (1928) 169-216 (Une lettre attribuée à Saint Athanase d'Alexandrie); M. Aubineau, Les écrits de S. Athanase sur la virginite, RAM 31 (1955) 140-173; S. Elm, Perceptions of Jerusalem pilgrimage as reflected in two early sources on female pilgrimage $\left(3^{\text {rd }}\right.$ and $4^{\text {th }}$ century A.D.), StPatr 20 (1989) 219-223; SWP 591.

${ }^{21}$ Por. Elm, Perceptions of Jerusalem, s. 220.

${ }^{22}$ Por. Egeria, Itinerarium ad loca sancta, CSEL 39, 37-101, lub CCL 175, 37-103, lub ed. P. Maraval, SCh 296, Paris 1982, thum. W. Szołdrski - A. Bogucki, PSP 6, Warszawa 1970, 160 241 lub OŻ 13, Kraków 1996, 135-229; DACL V 552-584 (Egeria); VII/2 1841-1842 (Itinéraires); SWP 130.

${ }^{23}$ Por. M. Starowieyski, Bibliografia Egeriana, „Augustinianum” 19 (1979) 297-331; tenże, Pielgrzymki do Ziemi Świętej, s. 152-153; tenże, Itinerarium Egeriae, „Meander” 33 (1978) 93-108 i 133-145; tenże, Pielgrzymka Egerii, w: Peregrinationes. Pielgrzymki w kulturze dawnej Europy, Warszawa 1995, 89-97; SWP 588; P. Devos, La date du voyage d'Egérie, AnBol 85 (1967) 165-194; tenże, Une nouvelle Égérie, AnBol 101 (1983) 43-70; tenże, Egeriana I, AnBol 105 (1987) 159-166; Egeriana II, AnBol 105 (1987) 415-424; Egeriana III, AnBol 109 (1991) 363-381.

${ }^{24}$ Por. T. Pikus, Próba rekonstrukcji ,Itinerarium” Egerii w oparciu o dzieto „,De locis sanctis” Piotra Diakona, „Meander” 36 (1981) 495-507; Starowieyski, Itinerarium Egeriae, s. 98. 
scami związanymi ze Starym Testamentem: 95 cytatów w jej tekście pochodzi z Starego Testamentu, a 23 z Nowego ${ }^{25}$. Egeria, jak wiele kobiet tego czasu, wyruszyła w pielgrzymkę w celach ascetycznych; mimo swej zamożności nie otaczała się przepychem, jak w przypadku opisanym przez Hieronima w liście $54^{26}$. Żyła skromnie i ponosiła ogromne trudy w pokonywaniu wielu wzniesień, czy uciążliwości pogody. Jechała w dość licznym gronie, a na trasie witali ją biskupi i mnisi, którzy objaśniali jej wydarzenia biblijne związane ze zwiedzanymi miejscami. Podróżowała utartymi trasami pielgrzymkowymi IV wieku. Jedynie wjazd do Mezopotamii i Edessy oraz Seleucji Izauryjskiej stanowił wyjątek od znanego wcześniej stereotypu.

Egeria uważała Palestynę za ziemię świętą; mówi też o relikwiach drzewa Krzyża Świętego, choć nie wspomina o kulcie relikwii. Zdaniem badaczy, niektóre otrzymane wiadomości przyjmuje Egeria bezkrytycznie (np. o krzaku Mojżesza, lub o kamieniu, na którym składali ofiary cielcowi). Zwiedzane miejsca tylko identyfikuje i ubogaca nieznanymi Biblii faktami, co zdaniem M. Starowieyskiego, mogło lec u podstaw powstawania legend biblijnych ${ }^{27}$. Wędrówce Egerii towarzyszyła swoista liturgia, wędrowała bowiem z egzemplarzem Pisma Świętego, na miejscu odmawiała modlitwę, odczytywała fragment Biblii i odpowiedni Psalm; często uczestniczyła także we Mszy świętej. Zdaniem znawców tematu, wszystko to wskazuje na liturgię jerozolimską, znaną z lekcjonarza armeńskiego i jego greckiego oryginału, powstałego na początku $\mathrm{V}$ wieku ${ }^{28}$. Egeria była zaopatrzona w pewien zbiór ksiąg, bowiem prócz Biblii i Onomastikonu Euzebiusza w przekładzie łacińskim, miała przy sobie - zdaniem Starowieyskiego - także apokryfy: Dzieje Tomasza, Dzieje Pawła i Tekli, Korespondencję Abgara i Chrystusa ${ }^{29}$, o czym świadczą użyte przez nią niektóre zwroty; najwięcej bowiem miejsca poświęca nadto Egeria właśnie pamiątkom po Abgarze i Odessie.

f). Grzegorz z Nyssy († ok. 390) w 381 r. pisze swój list zatytułowany O pielgrzymkach do Jerozolimy ${ }^{30}$, który jest wynikiem jego podróży do Jero-

${ }^{25}$ Por. A. Tafi, Egeria e la Bibbia, w: Atti del Convegno Internazionale sulla Peregrinatio Egeriae (Arezzo, 23-25 ottobre 1987), Arezzo 1990, 167, Starowieyski, Pielgrzymki do Ziemi Świętej, s. 152.

${ }^{26}$ Por. Hieronymus, Epistula 54, 8, thum. J. Czuj, ŹMT 55, 41.

${ }^{27}$ Por. Starowieyski, Pielgrzymki do Ziemi Świętej, s. 153.

${ }^{28}$ Por. Wilkinson, Jerusalem pilgrims, s. 252-266; Starowieyski, Itinerarium Egeriae, s. 135-138.

${ }^{29}$ Por. Starowieyski, Pielgrzymka Egerii, s. 93; tenże, Pielgrzymki do Ziemi Świętej, s. 154; zob. P. Delos, Égérie à Édesse. S. Thomas l'apôtre. Le roi Abgar, AnBol 85 (1967) 381-400.

${ }^{30}$ Por. Gregorius Nyssenus, Epistula 2 (De peregrinationibus ad loca sancta), PG 46, 1009 1016, lub ed. P. Maraval, SCh 363, 106-123, thum. T. Sinko: Św. Grzegorz z Nyssy, Wybór pism, Warszawa 1963, PAX, 225-230, przedruk: OŹ 13, 119-124; P. Maraval, Une querelle sur les pèlerinages autour d'un texte patristique (Grégoire de Nysse, Lettre 2), RHPR 66 (1986) 131-146; tenże, Égérie et Grégoire de Nysse pèlérins de Palestine, w: Atti del Convegno Internazionale sulla Peregrinatio Egeriae, s. 315-331; B. Kötting, Gregor von Nyssa's Wahllfahrtskritik, StPatr 5 (1962) 360-367; O poglądach Grzegorza z Nyssy, a także Grzegorza Wielkiego na temat relikwii pisze 
zolimy (Golgota, Anastasis, Góra Oliwna) i Betlejem. P. Iwaszkiewicz zwraca uwagę na szczególny atak Grzegorza na pielgrzymki ${ }^{31}$, bowiem mimo, że sam wybrał się do Jerozolimy, krytykuje pielgrzymki widząc w nich zagrożenie dla czystości wędrujących tam kobiet. M. Starowieyski porównuje drugi list Grzegorza z trzecim, który ma inny charakter, opowiada w nim bowiem o swych radosnych spotkaniach z miejscami świętymi, co jest - jego zdaniem - dowodem na proces spirytualizacji katechezy biblijnej tego czasu: w miejscach świętych widzi Grzegorz wręcz znaki wcielenia ${ }^{32}$.

g). Listy Hieronima o pielgrzymkach, zostały przetłumaczone przez J. Czuja, a omówione przez M. Starowieyskiego i P. Iwaszkiewicza. W listach tych Hieronim raz zachęca do pielgrzymowania w celu nawiązania bliższego kontaktu z Chrystusem, innym razem przestrzega przed zbytnim przecenianiem wartości pielgrzymki; gdzie indziej opisuje także pielgrzymkę Pauli do Jerozolimy, która odbyła się w 386 roku $^{33}$. Zwiedziła ona miejsca związane zarówno ze Starym, jak i Nowym Testamentem. Opisując wspomnienia Pauli Hieronim alegoryzuje wydarzenia Nowego Testamentu, co wskazuje, zdaniem badaczy, na istnienie w tym czasie egzegezy alegoryczno-chrystologicznej miejsc świętych. W liście do Fabioli opisuje wyjście Izraelitów z Egiptu i ich pobyt na pustyni oraz znaczenie duchowe każdego postoju Izraelitów ${ }^{34}$. List do Dardana zawiera opis granic Ziemi Świętej ${ }^{35}$.

h). Nil z Ancyry w Galacji († 430). Jeden z największych mistrzów duchowych starożytności na Wschodzie, uczeń Jana Chryzostoma, w mowie na cześć mnicha Albiana, pisze o swej pielgrzymce do Ziemi Świętej informując, że udał się ,aby prowadzić życie ascetyczne tam, gdzie Pan Jezus żył, działał cuda i poniósł śmierć, i żeby poznać te miejsca"36.

i). Ps-Eucheriusza, List do Fausta Prezbitera o położeniu Jerozolimy datowany na V lub VIII wiek; wymienia go i omawia P. Iwaszkiewicz ${ }^{37}$. Eucheriusz był biskupem Lyonu żyjącym w V wieku ale przyjmuje się, że ten list jest falsyfikatem i był pisany po 700 roku. Pół listu Eucheriusza to jego słowa,

z punktu antropologicznego: J. Domański, Antropologiczna refleksja nad relikwiami, w: Peregrinationes, s. 29-38.

${ }^{31}$ Por. Iwaszkiewicz, Wczesnochrześcijańskie i późnoantyczne łacińskie opisy podróży, s. 101.

${ }^{32}$ Por. Starowieyski, Pielgrzymki do Ziemi Świętej, s. 155.

${ }^{33}$ Por. Hieronymus, Epistolae 46, 58, 108, 129, 147, tłum. J. Czuj, ŹMT 54, 186-194; ŻMT 55, 69-76; ŹMT 61, 159-188; ŹMT 63, 183-190; SWP 591; Starowieyski, Pielgrzymki do Ziemi Świętej, s. 148 i 155-157; P. Maraval, S. Jérôme et le pèlerinage en Palestine, w: S. Jerôme entre l'Orient et l'Occident, Paris 1988, 350.

${ }^{34}$ Por. Epistula 78, ŹMT 55, 205-234; zob. Iwaszkiewicz, Wczesnochrześcijańskie i późnoantyczne tacińskie opisy podróży, s. 99.

${ }^{35}$ Por. Epistula 129, ŹMT 63, 183-190; zob. Iwaszkiewicz, tamże.

${ }^{36}$ Nilus, Oratio in Albianum, PG 79, 704B; SWP 591.

${ }^{37}$ Ps-Eucherius, Epistula de situ Hierosolymae ad Faustum Presbyterum, ed. P. Geyer, CSEL 39, 126-134; lub ed. I. Fraipont, CCL 175, 237-243, tłum. P. Iwaszkiewicz, „Meander” 45 (1990) 304-309. 
natomiast reszta to cytaty z 129 . listu Hieronima ${ }^{38}$. Dane topograficzne czerpał on z Hieronima, a także z łacińskiego przekładu Hegezypa Wojny Żydowskiej Józefa Flawiusza (tzw. Józef Łaciński); z tych samych źródeł czerpał później Adamnan (Irlandia VII w.), stąd hipoteza, że korzystał z niego ${ }^{39}$. Zdaniem Iwaszkiewicza, nie można jednak wykluczyć, że tekst pochodzi z V wieku, i że Eucheriusz i Adamnan korzystali z podobnych źródeł ${ }^{40}$.

j). Breviarius de Hierosolyma omawia A. Bober i P. Iwaszkiewicz ${ }^{41}$. Pisany był na przełomie V i VI wieku, nieporadnym stylem i okropną łaciną - jak piszą jego badacze. To anonimowy wykaz miast i zbiór krótkich informacji o rzeczach godnych zobaczenia w Jerozolimie i jej okolicach (Bazylika Konstantyna, wzgórze Golgoty, Syjon, dom Piłata i Kajfasza, resztki świątyni Salomona, dolina Jozefata). Autor zna też tradycję mówiącą, że Golgota była miejscem stworzenia Adama, Ofiary Izaaka i śmierci Chrystusa.

k). O położeniu Ziemi Świetej Teodozjusza powstało prawdopodobnie między 518-530 rokiem. Jest to, jak pisze Iwaszkiewicz, chaotyczny opis miejsc świętych w Palestynie, Azji Mniejszej, Egipcie, Syrii i Mezopotamii ${ }^{42}$. Zawiera opis różnych miejsc na terenie Palestyny, specjalnie ulokowanych przez autora blisko Jerozolimy, by odległość nie odstraszała pielgrzymów. Opowiada o lokalnych tradycjach i legendach, m.in. przytacza legendę o męczeńskiej śmierci św. Klemensa Rzymskiego w Chersonezie, utopionego z kotwicą u szyi; opisuje także doroczne uroczystości ku jego czci.

1). Itinerarium Antonina z Piacenzy powstało ok. 570 r., a omawia je i thumaczy P. Iwaszkiewicz ${ }^{43}$. Jego autorem jest bliżej nieznany czciciel św. Antonina z Piacenzy, pod którego opieką nieznany autor odbył pielgrzymkę. Tekst jest pośpiesznie zredagowany i ma charakter reportażu, bowiem - jak twierdzi P. Iwaszkiewicz - autor jest zainteresowany raczej codziennym życiem, niż sprawami religijnymi, a oprócz szczegółów dotyczących zwiedzanych miejsc,

${ }^{38}$ Por. Iwaszkiewicz, Wczesnochrześcijańskie i późnoantyczne łacińskie opisy podróży, s. 100.

${ }^{39}$ Por. A. Bober, Antologia Patrystyczna, Kraków 1965, 465; zob. też Hieronymus, Epistula 129, 4-5; Hegesippus, Bellum Judaicum V 6.

${ }^{40}$ Por. List biskupa Eucheriusza do Faustusa, „Meander” 45 (1990) 304-309. P. Iwaszkiewicz daje ciekawą argumentację za tym, że dzieło pochodzi z V w. i ze środowiska wyspiarzy w Lerynie za czasów Faustusa Bryta.

${ }^{41}$ Por. Breviarius de Hierosolyma, CSEL 39, 153-155, lub ed. R. Weber, CCL 175, 109-112; Iwaszkiewicz, Wczesnochrześcijanskie i późnoantyczne łacińskie opisy podróży, s. 99; A. Bober, Breviarius de Hierosolyma, „Częstochowskie Studia Teologiczne” 1 (1973) 263-266; zob. też Maraval, Les Itinéraires, s. 291; SWP 588.

${ }^{42}$ Por. Theodosius, De situ terrae sanctae, ed. P. Geyer, CSEL 39, 135-150, lub CCL 175, $113-$ 125, thum. P. Iwaszkiewicz: O położeniu Ziemi świętej, „Meander” 45 (1990) 225-237; Iwaszkiewicz, Wczesnochrześcijańskie i późnoantyczne łacińskie opisy podróży, s. 99-100; SWP 588.

${ }^{43}$ Por. Antoninus Placentinus, Itinerarium, ed. P. Geyer, CSEL 39, 159-191 lub CCL 175, $127-$ 174; zob. P. Iwaszkiewicz: Antoni z Piacenzy, Opis pielgrzymki do Ziemi Świętej, OŻ 13, 237-273. 
opisuje osobliwości i obyczaje Żydów, Saracenów i Samarytan ${ }^{44}$. Niektóre opisy wskazują nawet na pogoń za cudownościami.

1). Ody anakreontejskie Sofroniusza Jerozolimskiego († 638), pochodzące z pocz. VII wieku; autor w 19. odzie opisuje Jerozolimę widzianą z Góry Oliwnej, a w odzie 20. Betlejem. Zdaniem badaczy, opis ten ma charakter liryczny, a w tej ostatniej mówi nawet o „tęsknocie za świętym miastem i świętymi miejscami" ${ }^{45}$.

3. Wiek VII-VIII. Z okresu VII-VIII wieku pochodzą źródła, które wyznaczają kolejny nowy etap w podejściu do pielgrzymek, relikwii i pasji Chrystusa. Ich odmienny charakter wynika z historycznych wydarzeń - najazdów arabskich, które utrudniały lub wręcz uniemożliwiały pielgrzymki do Jerozolimy. Źródła te są pisane nie przez tych, którzy sami odwiedzali Jerozolimę, ale przez osoby, które spisały wspomnienia innych pielgrzymów, lub skopiowały ich wcześniejsze przekazy; pisane są zawsze ku wzmocnieniu wiary i ku zachęcie do modlitwy. Mają przewaznie charakter moralizujący pielgrzymowanie jest $\mathrm{w}$ nich przedstawione jako wzór ascetyczny (Waleriusz z Bierzo). Gdzie indziej znów są formą prośby o łaskę Bożą, czy wręcz rodzajem modlitwy apotropaicznej, chroniącej przed wszelkim złem (Adamnan).

a). List do braci mnichów Waleriusza z Bierzo († 691), wizygockiego mnicha będący kopią itinerarium Egerii; list ten thumaczy i omawia P. Iwaszkiewicz $^{46}$. Waleriusz z Bierzo (Vierzo), urodzony niedaleko Astorgi w prowincji Galicja, napisał to itinerarium ku czci Egerii w latach 675-680: ma ono formę listu i skierowane jest do braci mnichów z Bierzo.

b). O miejscach świętych irlandzkiego mnicha Adamnana z Iona († 704), będące spisaną relacją z podroży do Ziemi Świętej pielgrzyma, galijskiego biskupa Arkulfa ${ }^{47}$, który w wyniku perturbacji pogodowych dotarł łodzią do

${ }^{44}$ Por. Iwaszkiewicz, Wczesnochrześcijańskie i późnoantyczne łacińskie opisy podróży, s. 100; SWP 588-589; Maraval, Les Itinéraires, s. 291.

${ }^{45}$ Por. Sophronius Hierosolymitanus, Anacreontica 19-20, PG 87/3, 3812-3824; Bober, Antologia patrystyczna, s. 630-631; SWP 591.

${ }^{46}$ Por. Valerius Bergidensis, Epistula de beatissimae Egeriae laude conscripta fratrum bergidensium monachorum (CPL 1276), ed. M.C. Díaz y Díaz, SCh 296, 336-349, thum. P. Iwaszkiewicz: List ku czci błogosławionej Egerii napisany przez Waleriusza dla braci mnichów z Vierzo, „Meander" 46 (1991) 147-152; Z. Garcia, la Lettre de Valerius sur la bienheureuse Aetheria, AnBol 29 (1910) 377-399; Na temat Waleriusza i jego listu zob. M. Diaz y Diaz, Lettre de Valérius du Bierzo sur la bienheureuse Égérie. Introduction, SCh 296, Paris 1982, 323-334; C.M. Aherne, Valerio of Bierzo. An ascetic of the late Visigothic period, Washington 1949, 1-34.

${ }^{47}$ Por. Adamnanus, De locis sanctis, ed. P. Geyer, CSEL 39, Vienna 1898, 219-297, lub ed. L. Bieler, CCL 175, Turnhout 1956, 183-234, tłum. P. Iwaszkiewicz, OŻ 13, 283-357. Ponadto po polsku ukazały się fragmenty tego itinerarium w thum. A. Bobera w: Studia i teksty patrystyczne, Kraków 1967, 67-79 oraz w: tegoż, Anglia. Szkocja. Irlandia. Teksty żródłowe do historii Kościoła i patrystyki I-IX wieku, Lublin 1991, 38-42. 
Wysp Brytyjskich i przybył do klasztoru na wyspie Iona ${ }^{48}$. Opatem tego klasztoru był wówczas Adamnan, który wspomnienia Arkulfa najpierw spisał na tabliczkach, a później odtworzył je na pergaminie ${ }^{49}$. Podróż Arkulfa odbyła się prawdopodobnie ok. 683/4 r., a została spisana przed 688 rokiem. Adamnan opisuje zarówno rzeczywiste świadectwa epoki, jak i legendarne miejsca i przedmioty dewocji. W I księdze opisuje m.in.: budowle Grobu Pańskiego i Kalwarii, bazylikę Konstantyna i bazylikę na Górze Syjon, bramę Dawida i relikwie, które pozostały po męczeńskiej śmierci Chrystusa (włócznia, całun) oraz miejsce Jego Wniebowstąpienia, grobowce Symeona i Józefata, miejsce śmieci Judasza, grób Łazarza i klasztor przy nim wzniesiony, winnice Góry Oliwnej, kościół w Betanii oraz miejsca i krajobrazy pomiędzy Jerozolimą a Cezareą Palestyńską. W II księdze Adamnan opisuje m.in. Betlejem, groby Racheli, Dawida i św. Hieronima, Dolinę Mambre, Jerycho, Morze Martwe i Galilejskie oraz rzekę Jordan, miejsce, gdzie został ochrzczony Chrystus przez św. Jana oraz sadzawkę w Samarii, Kafarnaum i kościoły Nazaretu, Górę Tabor, Damaszek i Tyr; na koniec opisuje Aleksandrię i rzekę Nil.

c). O miejscach świetych Bedy Wielebnego († 735), napisane w latach 702-703, liczy 18 rozdziałów i jest niemal zupełną kopią dzieła Adamnana ${ }^{50}$. W zakończeniu Beda informuje nas, że dzieło swe napisał w oparciu o prace dawnych historyków, a przede wszystkim Adamnana; w swej Historii Kościelnej nazywa nawet swe dzieło „Zwięzłym streszczeniem” jego pracy ${ }^{51}$.

d). Z poł. VIII wieku pochodzi: Opis miejsc świętych w języku greckim Epifaniusza z Jerozolimy zwanego Epifaniuszem Hagiopolitą przetłumaczony na starocerkiewno-słowiański ${ }^{52}$ oraz $\dot{Z} y$ wot św. Wilibalda Hegeburga, opisujący podróż do Jerozolimy w latach 720-729 anglosaskiego mnicha i biskupa Eichstadt Willibalda, współpracownika i biografa ewangelizatora Germanii św. Bonifacego ${ }^{53}$; te dwa ostatnie opisy są mało znane i słabo opracowane.

${ }^{48}$ Trasę podróży Arkulfa z Palestyny do Iona rekonstruuje L. Bieler opierając się na De locis sanctis Adamnana we wstępie do swego wydania, CCL 175, 183-234.

${ }^{49}$ Spisał je na drewnianych bądź kościanych tabliczkach pokrytych woskiem lub obciagniętych skórą, por. Adamnán's ,, De locis sanctis”, ed. D. Meehan, introd. L. Bieler, Scriptores Latini Hiberniae (= SHL), vol. 3, Dublin 1958, 34; P. Riché, Edukacja i kultura w Europie Zachodniej (V-VIII wiek), tłum. M. Radożycka-Paoletti, Warszawa 1995, 466.

${ }^{50}$ Por. Beda Venerabilis, De locis sanctis, ed. P. Geyer, CSEL 39, 301-324, lub ed. I. Fraipont, CCL 175, 251-280.

${ }^{51}$ Por. Beda Venerabilis, Historia Ecclesiastica V 15, PL 95, 256; SWP 589-590.

${ }^{52}$ Por. Iwaszkiewicz, Wczesnochrześcijańskie opisy podróży, s. 101; H. Donner, Die Palästinabeschreibung des Epiphanius Monachus Hagiopolita, „Zeitschrift des Deutschen Palästina-Vereins” 87 (1971) 54-59.

${ }^{53}$ Por. Hegeburgus, Vita Sancti Willibaldi, ed. O. Holder-Egger, MGHScript. XV 86-106. To relacja ubogiego pątnika ukazująca sytuację na Bliskim Wschodzie za panowania arabskiego, zob. P. Iwaszkiewicz, OŻ XIII 59-60 ( bibliografia); Wilkinson, Jerusalem pilgrims, s. 125-135. 
3. Podsumowanie. Na przestrzeni IV wieku nastąpiła stopniowa ewolucja w podejściu do pielgrzymki i pojęcia miejsca świętego. Niektórzy autorzy twierdzą, że pielgrzymki zawdzięczają swą „legalizację" panowaniu Konstantyna Wielkiego ${ }^{54}$. Jednak nawet pielgrzymka Heleny, matki cesarza Konstantyna, z 326 r., której nadano rozgłos, nie spowodowała zbytniego wzrostu pielgrzymek $^{55}$. Wydaje się, że moment wybuchu pielgrzymowania do Ziemi Świętej w celach duchowych należy wyznaczyć na poł. IV wieku lub później. Wówczas praktyka udawania się ad loca sancta żeńskich ascetek (parthenoi) stała się popularna. Prawdopodobnie jednak i ona nie ma jeszcze charakteru duchowego. Ks. M. Starowieyski twierdzi wręcz, że nawet pielgrzymka Egerii z końca IV wieku nie stanowiła jeszcze przeżycia religijnego ${ }^{56}$. Tekst Egerii stanowi wprawdzie, jego zdaniem, postęp od czasów pielgrzyma z Bordeaux, ale Egeria nie czyni nic w kierunku objaśnień duchowych, znanych $\mathrm{z}$ katechezy pielgrzymkowej dla katechumenów przybywających do Jerozolimy, prowadzonych po syryjsku, grecku, i łacinie ${ }^{57}$. Należy jednak zauważyć, że pielgrzymka Egerii trwała trzy lata i trud tak długiego pielgrzymowania, związanego z wielkim wysiłkiem pokonywania drogi, trudów pogody i ukształtowania terenu (wspinaczka), trudno tłumaczyć innymi względami niż duchową desperacją i wiarą w szczególny sens pielgrzymki. Lakoniczny styl Itinerarium Egerii może wynikać z panujących zwyczajów literackich. Od poł. IV wieku, Jerozolima stała się „Mekką dla «milionerek» tamtych czasów, które niekiedy dla poszerzenia swoich wpływów w swoim środowisku, jechały do Jerozolimy po relikwie"58; wszystko to spotka się z krytyką Grzegorza z Nyssy.

Atanazy, Grzegorz z Nyssy i Hieronim przyczynili się do tego, że nastąpiło przejście od pielgrzymki postrzeganej jako podróż o charakterze poznawczym, do pielgrzymki mającej na celu duchowe wsparcie i duchową przemianę ${ }^{59}$. Zdaniem E. Wipszyckiej, Hieronim pisze już w epoce rozwijającego się ruchu pielgrzymkowego ${ }^{60}$. Przyczyn intensywnego rozwoju pielgrzymek doszukuje się ona w nowych zjawiskach religijności: eksplozji kultu świętych, narodzi-

${ }^{54}$ Por. Wipszycka, Pielgrzymki starożytne, s. 25; J. Wilkinson, Jewish holy places and the origins of Christian pilgrimage, w: The blessings of pilgrimage, ed. R. Ousterhout, Urbana 1990, 43.

${ }^{55} \mathrm{O}$ pielgrzymce Heleny pisze Sokrates Scholastyk ok. poł. V wieku w swej Historii Kościoła (HE I 17, SCh 477, 174-181, tłum. S. Kazikowski, Warszawa 1986, 109-112), a także jego kontynuator Hermiasz Sozomen (HE II 1-2, SCh 306, 226-237, thum. S. Kazikowski: Historia Kościoła, Warszawa 1989, 80-84); zob. też. H.D. Drake, A Coptic version of the discovery of the Holy Sepulchre, „Greek, Roman and Byzantine Studies” 20 (1970) 381-382; A. Frolow, La relique de la vraie Croix, Paris 1967.

${ }^{56}$ Por. Starowieyski, Pielgrzymka Egerii, s. 94- 95.

${ }^{57}$ Por. Starowieyski, Pielgrzymki do Ziemi Świętej, s. 154.

${ }^{58}$ Por. Mango, The Pilgrim's motivation, s. 7; E.D. Hunt, St. Silvia of Aquitaine, JTS 23 (1972) 351-373.

${ }^{59}$ Por. Wilkinson, Visits to Jewish, s. 455.

${ }^{60}$ Por. Wipszycka, Pielgrzymki starożytne, s. 24. 
nach kultu maryjnego i upowszechnieniu ruchu monastycznego. Szczególną wagę przypisuje też roli cudów w mentalności chrześcijan, których pragnienie rośnie w 2. poł. IV wieku i upowszechnia się sąd, że Bóg lepiej wysłuchuje modlitw w określonych miejscach. Następuje, jak zauważa, wzrost poczucia zagrożenia ze strony szatana, przed którym łatwiej bronić się w naznaczonych sacrum miejscach, które nazywa wyrwanymi złemu wycinkami przestrzeni ${ }^{61}$. Przekonanie o nierównomiernym występowaniu sacrum w przestrzeni spowodowało, jej zdaniem, powstanie skomplikowanej geografii sakralnej, a kult świętych i translacje relikwii pozwalały na znaczne ich zagęszczenie. Wszystkie te zjawiska spowodowały, jej zdaniem, kurczenie się grup ludzi podróżujących z pobudek nie mających wiele wspólnego z religijnością ${ }^{62}$.

$\mathrm{W}$ ciagu $\mathrm{V}$ wieku pojawiły się nowe zjawiska peregrynacji, jak rola relikwii, cudów i cudowności oraz związanych z nimi legend hagiograficznych. Konsekwencją tych zjawisk było także rozprzestrzenienie się eulogii, ikon i świątyń (także w celu inkubacji), co było sprawą nie tylko chrześcijan, jak pisze C. Mango, ale także Żydów, pogan i sceptyków ${ }^{63}$. Od VI wieku nastąpił wręcz rozwój rynku dewocjonaliami. G. Vikan dokonuje ciekawej analizy relacji między pielgrzymkami a szerokim zjawiskiem powstawania dewocjonaliów i eulogii w okresie VI-VII wieku. Rozważa je z punktu widzenia m.in. tamtejszej architektury, ikonografii i magii apotropaicznej; ważnym materiałem do tej analizy były dla niego także ampułki z Ziemi Świętej, ikony i szkła magiczne ${ }^{64}$.

Przejawem postępujących tendencji był także rozkwit kultu Drzewa Krzyża Świętego. Od końca IV wieku aż do VII wieku Jerozolima stała się centrum kultu Krzyża. Na początku VII wieku Persowie zniszczyli większość kościołów Jerozolimy wywożąc również relikwie Krzyża Świętego. Odzyskał je cesarz bizantyjski, Herakliusz w 628 r.; wtedy też kompleks Grobu Świętego odbudowano, a relikwie Krzyża ze względu na zagrożenie arabskie przewieziono do Konstantynopola, do bazyliki Hagia Sophia ${ }^{65}$. Rozpowszechniły się także ceremonie Wielkiego Czwartku, znane także na Zachodzie już w V wieku ${ }^{66}$.

${ }^{61}$ Por. tamże, s. 27.

${ }^{62}$ Por. tamże, s. 28.

${ }^{63}$ Por. Mango, The Pilgrim's motivation, s. 8

${ }^{64}$ Por. G. Vikan, Early Byzantine pilgrimage devotionalia as evidence of the appearance of pilgrimage shrines, w: Akten des XII Internationalen Kongresses für Christliche Archäologie, Münster 1995, 377-388. G. Vikan tworzy tezę, że rozwój ikon, dewocjonaliów i eulogii, to następstwo niedostępności Jerozolimy pod arabskim panowaniem. O eulogiach zob. też E. Jastrzębowska, Najstarsze zachowane dewocjonalia pielgrzymie z Jerozolimy, w: Jerozolima w kulturze europejskiej, red. P. Paszkiewicz - T. Zadrożny, Warszawa 1997, 59-68.

${ }^{65}$ Nastąpiło to z pewnością przed 638 r. (data zajęcia Jerozolimy przez Arabów), por. A. Florow, La relique de la vraie Croix, Paris 1967, 188.

${ }^{66}$ Ceremonie kultu Drzewa w Rzymie w Wielki Czwartek opisuje skomponowany w końcu VII wieku ceremoniał Ordines Romani, por. M. Andrieu, Les Ordines Roman du Haut Moyen Age, vol. 2, Louvain 1971, 67-107; Wilkinson, Jerusalem pilgrims, s. 138-139; zob. Egeria, Itinerarium 38, 1. 
W okresie, o którym mowa, następują narodziny różnych typów pielgrzymek praktykowanych przez następne stulecia. Ze względu na cel i sposób realizacji: peregrinatio ad loca sancta, peregrinatio ascetica będąca ekwiwalentem vita monastica oraz pielgrzymka millenarystyczna ${ }^{67}$. Pierwszy pojawia się w początkowym okresie, jako impuls do zwiedzenia Groty narodzenia Chrystusa i Grobu Chrystusa, drugi rozwinął koncepcję homo viator obecną w źródłach VI-IX wieku, o trzecim mówią montaniści w kontekście idei Nowej Jerozolimy czasów paruzji ${ }^{68}$. Od XI wieku wchodzi także motyw eschatologiczny - pielgrzymka jerozolimska jako ostatnia podróż w życiu, powiązana $\mathrm{z}$ nadzieją na bliską paruzję, o której pisze A. Witkowska ${ }^{69}$. Zwraca ona uwagę na uniwersalny i ponadczasowy wymiar zjawiska peregrinatio religiosa, szeroko znanym także w kręgu kultur antycznych, religii wschodnich i judaizmie; w chrześcijaństwie zaś znanej jako typ pielgrzymki ascetycznej ${ }^{70}$. Głównym jej motywem była idea uświęcania się poprzez oddalenie od własnego środowiska i odrzucenie bezpiecznego życia mniszego, a także poszukiwanie mistrza lub świątobliwego męża. Z czasem wyłonił się z niej inny typ pielgrzyma - wędrującego kaznodziei. Witkowska wskazuje na List do Hebrajczyków (11, 8-10) jako podłoże ascezy mnichów wschodnich. Syryjski model życia monastycznego to, zdaniem znawców tematu, życie wiecznego noma$\mathrm{da}^{71}$. Chrześcijańskie pojecie peregrinatio jako dobrowolne wygnanie i ważny aspekt ascetyzmu, ma swe źródło głównie w pismach Ojców Pustyni ${ }^{72}$.

${ }^{67}$ Por. Elm, Perceptions of Jerusalem, s. 220-223.

${ }^{68}$ Por. A. Guillaumont, Le d'epaysement comme forme d'ascèse dans le monachisme ancien, „Annuaire de l'École Pratique des Hautes-Études” 76 (1968-1969) 29-58; G.B. Ladner, Homo viator: medieval ideas on alienation and order, „Speculum” 42 (1967) 233-259; T.D. Barnes, The chronology of Montanism, JTS 21 (1970) 403-408; W. Calder, The New Jerusalem of the Montanists, „Byzantion” 6 (1931) 421-425; C. Deluz, Pier a Jérusalem. Permanence et évolution d'après quelques recits de pélerins occidentaux $d u V^{k}$ au $X V^{k}$ siècles, w: tenże, La prière au moyen âge, Aix-de-Provence 1981, 189-210; La dimora di Dio con gli uomini (Ap. 21.3). Immagni della Gerusalemme celeste dal III al XIV secolo, ed. M.L. Gatti Perer, Milano 1983; J. Leclerq, Monachisme et pélègrination du IXe au XII siècle, SMon 3 (1961) 33-52; S. Kobielus, Niebieska Jerozolima. Od sacrum miejsca do sacrum modelu, Warszawa 1989.

${ }^{69}$ Por. Witkowska, Peregrinatio religiosa, s. 13.

${ }^{70}$ Por. tamże, s. 9-11; zob. R. Roussel, Les pèlerinages à travers les siècles, Paris 1954; Les pèlerinages de l'antiquité bibliques et classique à l'Occident medieval, Paris 1973; Maraval, Lieux saints et pèlerinages d'Orient, Paris 1985; Histoire des pèlerinages non chrétiens. Entre magique et sacré: le chemin des dieux, ed. J. Chelini - H. Branthomme, Paris 1987.

${ }^{71}$ Por. H.F. Campenhausen, S'expatrier à cause de la foi, „La Vie Spirituelle” 101 (1959) 165nn; M. Kanior, Historia monastycyzmu chrześcijańskiego, t. 1: Starożytność, Kraków 1993, 116nn.

${ }^{72}$ Por. G.E. Goud, Moving on and staying put in the Apophthegmata Patrum, StPatr 20 (1989) 231-237; H.F. Campenhausen, The ascetic idea of exile in ancient and early medieval monasticism, w: tenże, Tradition and life in the Church, London 1968, 233-240; P. Nagel, Die Motivierung der Ascese in der alten Kirche und der Ursprung des Mönchtums, TU 95, Berlin 1966, 90-98. 
Wartym odnotowania jest fakt, że wszystkie wczesne itineraria dotyczą Jerozolimy: nie posiadamy natomiast wczesnych przekazów mówiących o peregrynacjach do Rzymu. Itineraria Hierosolymitana dotyczą Palestyny, Egiptu, Syrii i Konstantynopola. Z wcześniejszych źródeł na temat Rzymu znany jest tylko zbiór poezji Prudencjusza, zwłaszcza jego hymn o Hipolicie ${ }^{1}$. Pierwsze skromne dokumenty dotyczące pielgrzymek do Rzymu pochodzą dopiero $\mathrm{z}$ VII wieku. W wydanych niedawno Itineraria et alia geographica zebrano szczątkowe dokumenty odnoszące się do Rzymu². To co zebrano, jak piszą autorzy Słownika wczesnochrześcijańskiego piśmiennictwa ${ }^{3}$, ma charakter zwięzłych wykazów czy katalogów. To suchy wykaz relikwii męczenników, spis cmentarzy, wykaz kościołów w mieście i poza miastem, spis bram miasta i informacje o prochach świętych pańskich (w dokumencie Itinerarium Malmesburiense), także dokumenty epigraficzne i historyczne dotyczące Rzymu (w dokumencie Itinerarium Einsidlense).

Temat pielgrzymek, pielgrzymowania, itinerariów, przeżyć duchowych wynikających z kontaktu z miejscem świętym, elogiów, dewocjonaliów i inskrypcji, to ciągle ważny temat badań dla historyków Kościoła i teologów, antropologów, religioznawców i językoznawców, a także archeologów i historyków sztuki. Prócz wymienionych wyżej polskich publikacji zbiorowych, dotyczących pielgrzymek (Do Ziemi Świętej, Peregrinationes oraz „Studia Kazimierskie" t. 5), swego rodzaju podsumowanie tej problematyki, także w kontekście innych religii, znajdziemy w innych dwóch pozycjach.

Pierwsza dająca materiały archeologiczne, to publikacja Kongresu Archeologii Chrześcijańskiej, który odbył się w Bonn w 1991 r., wielokrotnie wyżej cytowana ${ }^{4}$. Na uwagę zasługują $\mathrm{w}$ niej, prócz wymienionych wyżej pozycji C. Mango, J. Wilkinsona i G. Vikana, także artykuły P. Donceel-Voute (poświęcona relikwiarzom), I. Shahida (poświęcona pielgrzymce islamskiej) oraz É. Ó Carragáina (na temat relacji między rzymską liturgią i pielgrzymkami a Ruthwell Cross w Anglii).

Druga to wydana w 2005 r. w Oxford Pilgrimage in Greco-Roman and early Christian antiquity: seeing the gods, pod redakcja J. Elsnera i I. Rutherford $^{5}$, gdzie problem pielgrzymek i pielgrzymowania autorzy rozważaja raczej w kontekście antropologicznym i międzyreligijnym (definicja pojęć, terminologia, teoria pielgrzymki, ciagłość tradycji) na bazie materiałów ze

${ }^{1}$ Por. Prudentius, Peristephanon XI, CCL 126, 370-378, tłum. M. Brożek: Wieńce męczeńskie, XMT 40, Kraków 2006, 309-323; zob. też A. Bober, Antologia patrystyczna, Kraków 1965, 567-571.

${ }^{2}$ Por. Itineraria et alia geographica, CCL 175, Turnholti 1965, 284-343.

${ }^{3}$ Por. SWP 590.

${ }^{4}$ Por. Akten des XII. Internationalen Kongresses für christliche Archäologie (Bonn, 22-28 September 1991), ,Jahrbuch für Antike und Christentum. Ergänzungsband” 20/1, Teil 1-2, Münster 1995.

${ }^{5}$ Por. Pilgrimage in Graeco-Roman and early Christian antiquity. Seeing the Gods, ed. J. Elsner - I. Rutherford, Oxford 2007. 
starożytnego Wschodu, hellenistycznych, greckich i rzymskich oraz żydowskich i chrześcijańskich. Na uwagę zasługuje Wprowadzenie redaktorów (ss. 1-38), którzy prezentują w nim starożytną typologię podróży rozumianych jako pielgrzymka (m.in. w celu uzdrowienia, inicjacji, dedykacji, oddania czci, upamiętnienia bitew, utwierdzenia tradycji) oraz artykuły dotyczące pielgrzymki chrześcijańskiej, m.in. W. Pullan (pielgrzymka w kontekście pojęcia alienacji, pojęcia obcy - wygnaniec) i J. Elsnera (pielgrzymka a kształtowanie się liturgii).

\section{CHRISTIAN ITINERARIA TO THE HOLY PLACES FROM THE II TO VIII CENTURY}

(Summary)

The article is a summary of Christian itineraria, documents and letters from a trip to the Holy Land; from Meliton of Sardis letter's in the second century, to description of the holy places in Greek Epiphanius of Jerusalem in the eighth century. The author touches the theme of evolution in the approach to the pilgrimage over seven centuries. At the beginning the journey to Jerusalem was sightseeing, historical and descriptive. From the fourth century, pilgrimage becomes the religious and spiritual journey. In the sixth century it is great phenomenon of religion (the cult of the Holy Wood of the Cross, the cult of relics, eulogia) but also political. From the beginning was associated with the ascetic and monastic ideals. Due to the invasion of Islam in the seventh and eighth centuries, itineraria were mostly copies of previous or notation of experiences of other people.

${ }^{6}$ Por. tamże, s. 383-409: W. Pullan, Intermingled until the end of time: ambiguity as a central condition of early Christian pilgrimage; s. 407-434: J. Elsner, Piety and passion: contest and consensus in the audiences for early Christian pilgrimage. 
